Livermore data may be

significant

\section{Washington}

US Department of Energy officials remain baffled about the cause of an abnormally high incidence of malignant melanoma among employees of the University of California's Lawrence Livermore Laboratory, one of the nation's centres for nuclear weapons research.

An advisory board report released in Washington last week confirmed findings suspected since 1976, and substantiated earlier this year by California's Department of Health Services, that the incidence of skin cancer among laboratory employees was three to four times the national average.

The California study showed that between 1972 and 1977, 19 white workers at the laboratory had developed malignant melanoma, compared with between 4.6 and 6.4 cases expected using national statistics, a result which it said was "very unlikely to have occurred by chance".

At the request of the Department of Energy, the data were reviewed by an advisory board chaired by Dr Arthur Upton, then director of the National Cancer Institute. The board found no flaws in the Californian study and revealed that the increased incidence seems to have continued, with eight more cases of melanoma being reported up to June 1980 .

However, the advisory board reports that preliminary efforts to explain the excess have not succeeded in implicating any specific cause. It says that the occupational safety, industrial hygiene and medical programmes of the laboratory appear to be well conceived and well conducted, and that additional protective health measures "appear to be unwarranted"'.

It also lists a range of possible environmental causes, from occupational exposure to chemicals to details of individual lifestyles, which it says should be studied in more detail to get to the root of the problem.

"Part of the difficulty is that there may be no problem at all. We still don't really know if this thing is real; it may be just a statistical fluke" stated one member of the board last week, pointing out that the continued high incidence could be the result of people looking for - and finding melanomas many years earlier than they would otherwise be detected.

Although a relatively rare form of cancer, the incidence of malignant melanoma has been increasing faster than almost any other cancer in recent years. In
San Francisco, for example, the number of cases rose from 5.8 to 11.2 per 100,000 between 1970 and 1975, and similar figures have been reported for other parts of the country.

One fashionable explanation is that, because the greatest increase has been found among fair-skinned professionals, whose work tends to keep them indoors, it may be caused by intermittent exposure to ultraviolet radiation, for example as a result of excessive sunbathing or other outdoor activity.

Preliminary examination of the occupational histories of those contracting skin cancer has failed to reveal any obvious common pattern of exposure to particular chemicals or forms of radiation, and the board's report points out that although malignant melanomas have been found in an irradiated person, epidemiological studies have failed to produce convincing evidence that tumours may be induced in the skin by ionizing radiation.

However, the possibility that occupational exposure to, for example, internal emitters and ultraviolet radiation may contribute to the aetiology of melanoma is one of several avenues that the laboratory intends to explore further. "It is just possible, because of changes in lifestyle such as improved nutrition, that we have managed to increase our risk of cutaneous melanoma to the point where, although radiation was not a cause in the past, it might have become one today", says Professor John A.H. Lee of the
Department of Epidemiology at the University of Washington in Seattle.

In a memorandum submitting the board's report to Energy Secretary Charles Duncan, the Department of Energy's Assistant Secretary for the Environment, Dr Ruth Clusen, suggests that further studies by both the laboratory and the state Department of Health Services should be supported.

The latter has already proposed a major follow-up programme, which is being reviewed by the department that will take a detailed look at the particular social characteristics of the Lawrence Livermore workforce. A parallel study may also be carried out at another Department of Energy site.

The Lawrence Livermore Laboratory is operated by the University of California under contract from the Department of Energy. Its involvement in weapons research - and the resulting need to keep much of the research programme secret has been the source of sharp controversy over whether its links with the university should be maintained.

Last year the university's board of regents rejected a call from California Governor Jerry Brown that all weaponsrelated research be moved to the Los Alamos Laboratory, and last month the regents agreed to start negotiations with the Department of Energy for a new management contract for the laboratory. The current contract expires in 1982 .

David Dickson

\title{
EEC worries about veal and hormones
}

The massive veal market in Europe, consuming eight million calves a year, was on the verge of collapse this week following scares in France and Italy over the levels of an artificial growth hormone - diethylstilboestrol - in the meat. Diethylstilboestrol (DES) is a synthetic oestrogen which caused vaginal cancers in the daughters of mothers who were prescribed it (in large doses) as a protection against spontaneous abortion in the 1940s and 1950s. Its use is banned in the United States and in most countries of Europe, but a black market has sprung up because this chemical can add $5-15 \mathrm{~kg}$ to the weight of a calf and thus double a farmer's profits.

In Italy, the trouble began on 4 September, when the Ministry of Health placed a temporary ban on twenty-two brands of baby foods containing veal. A fairly crude bioassay had shown samples to contain an active oestrogen, probably DES. On 22 September a local magistrate in Latina, south of Rome, used the wide powers of Italian magistrates to impose a nationwide ban on the sale of veal. The Rome laboratory of the Istituto Superiore di Sanita, the technical arm of the Ministry of Health, is now making mass spectroscopic measurements of the hormones isolated from the baby foods to check for DES. In the view of a British scientist, the levels are probably "quite high" or they would be undetectable by the original method.

In France, pressure began independently from the left-wing trades union group, Paysans Travailleurs, whose members had accumulated evidence that French veal producers were using the synthetic hormone. Paysans Travailleurs then recruited help from the consumer group, the Union Fédérale des Consommateurs, which called for a boycott of veal in the September issue of its magazine, Que Choisir. Subsequently, in a rare enforcement of French law on the matter, a 29-year-old pharmacist and veal producer was jailed.

Pressure from farmers and other interests has forced the Italian magistrate to relax his ban somewhat, but sales of veal have still fallen by $50-60$ per cent in both France and Italy, and the export of calves 
from Britain - where hormone use is controlled under the 1968 Medicines Act but not banned - has fallen to a trickle in a business normally worth $£ 500,000$ a week.

Last Tuesday agriculture ministers of the European Community tried to take a grip in the affair by promising that Commission officials would devise a scheme - within a couple of months - for uniform testing of hormone levels in meat throughout the

\section{EEC hormone law}

Belgium, Denmark, France, Italy and the Netherlands already have a total ban on the use of natural or artificial hormones, but avoidance is thought to be commonplace. Belgium, France and West Germany take the view that a partial relaxation of the ban in favour of natural hormones - oestradiol and testosterone - would stop the abuse of the synthetic hormone which can be injected directly into the muscle as an oily, crystalline suspension, and is not easily detected by visual inspection of the meat after the animal is slaughtered; other hormone preparations, however, are administered as pellets implanted prominently in the ear. The ear is discarded at the slaughterhouse, but injected muscle will find its way straight to the table - or the baby food.

West German legislation, at present, distinguishes a list of hormones which may be administered - the positive list and a list which may not - the negative list. On the latter are those which have an oral oestrogenic activity of more than one-fifth that of DES, so banning DES, the related hexoestrol, and two other artificial oestrogens. On the positive list at less than one-fifth the activity are the natural oestradiol and the artificial agent zeranol.

In Britain, the Medicines Act allows licensing of hormone preparations by the Veterinary Products Committee, under the Ministries of Agriculture and Health. Under these licences zeranol and hexoestrol are on free sale to farmers; and Hoecht's Finaplix (an androgen used in beef production) and Implixa (used for veal) administered by vets. The drugs may not be administered within at least 60 days of slaughter (although the drugs firms are pressing to reduce this period). The Pharmaceutical Society has the statutory authority to police the proper use of the drugs.

DES is no longer used in veal or beef production in Britain, although it is used occasionally in pig farming. One veal producer for the small $-70,000$ head a year - British home market, Philip Paxman of Volac Ltd, said last week that he had stopped using hormones at all because of public pressure; and they are rarely used in the 300,000 head export market, he believes, because calves are shipped at 4-6 weeks old for fattening on the continent.
EEC. Despite great pressure from Italy, however, the ministers drew back from imposing a total ban, but will not easily agree on the directive they have asked for.

UK specialists in the use of sex hormones in farming argue that any proposed European legislation should distinguish between artificial agents and natural steroids (like oestradiol and testosterone); and that the use of natural steroids should be limited to tissue levels of around 1 in $10^{9}$ - similar to those found in untreated farm animals. For the synthetic anabolic agents, and their frequently unknown residues, they should be shown to be non-toxic and non-carcinogenic before licensing.

European consumers unions, however, represented in Brussels by the Bureau Européen des Unions Consommateurs (BEUC) are pressing hard for all hormone use for meat production to be banned. It is too difficult for a policing authority to distinguish natural from unnatural hormones, says BEUC, so both should go. If agreed, this would have a big impact on beef production in the UK, which in the past few years has come to depend on hormone supplements for its profits, and would cause pressure to increase the use of antibiotics which have a similar effect on weight gain.

And perhaps Italy should worry more about olive oil than veal. According to one pharmaceutical company spokesman, vegetable oestrogens - of one-hundredth or so the bioeffectiveness of oestradiol, are present in olive oil at such a high level that the consumption of $50-100 \mathrm{~g}$ of olive oil a day would reverse an ageing woman's postmenopausal changes. But then if Italy can ban veal, it can probably ban olive oil too.

Robert Walgate

\section{Polish farming}

\section{More meat to eat?}

Agriculture is an extremely sensitive issue in Poland. After all, it was the announcement of increases in the price of meat products on 1 July that led to the recent wave of industrial unrest. Speaking last week at the Olsztyn AgriculturalTechnical Academy, the Polish President, Henryk Jablomski, explained that what Polish agriculture needs is a robust, up to date and consistent farm policy, which will take into account the needs of development, technical equipment and the "fullest possible utilization" of scientific achievements. In particular, there is a pressing need for people of "considerable professional qualifications and social dedication" to implement research and guide agricultural development.

Under clause 6 of the Gdansk accords, the Polish government undertook to create "lasting prospects for developing peasant family farms which are the foundation of Polish agriculture"'. The greater openness of information stipulated by clause 3 of the same accords means that for the first time official figures comparing the performance of state and private agriculture are being made available to the general public. Some 75 per cent of Polish agricultural land is still in private hands - some 3 million family farms of which barely 400,000 exceed 10 hectares. A minimum of $\mathbf{1 5 - 2 0}$ hectares is considered necessary for really efficient farming in Polish conditions, hence the large state farms would be expected to have the most advantages particularly because the state sector receives 64 per cent of all investment in agriculture. Yet, according to the official figures for 1979 (quoted by Leszek Chmielowski in Zycie Warszawy, 23 September), the state sector uses 2.5 times more chemical fertilizers and $\mathbf{2 . 6}$ times more concentrated feedstuffs to give the same amount of produce.

Chmielowski suggested that subsidies to state farms should be reduced, administrative costs minimized and unrealistic plans phased out. The land fund (largely made up of former private farms handed over to the state in return for a pension by elderly farmers without an heir eligible to succeed them) should not, said Chmielowski, simply be used to increase the area of (often unproductive) state farms, but should be made available to all private farmers who wish to expand.

Nevertheless, the members of the new "self-governing" farmers' union feel that Chmielowski's proposals do not go far enough. He stressed, for example, that the state sector, properly organized, still has "an important and growing role to play". But as Wieslaw Kecik, a young intellectual temporarily coopted as an "assistant" to the new union, explained, the greatest deterrent to the ambitious private farmer is his lack of security of tenure. Official policy, since the early 1970 s, has aimed at "collectivisation without loss of production". If the state sector is to grow, the private farmers feel, it can only do so at their expense.

Moreover, said $\mathrm{Mr}$ Kecik, there are considerable price differentials in favour of the new sector. The private farmer must pay more for all essentials, and receives lower prices for his produce, except for a few "commercial" crops such as rape-seed and flax. Abolition of such inequalities, and the guarantee of land tenure, "must be", said Mr Kecik, "basic postulates of the new self-governing farmers' union"'.

The day after Chmielowski's article appeared, the Prime Minister, Josef Pinkowski, addressed a meeting of farmers and agricultural workers in terms of apparent reassurance. After calling on all those engaged in agriculture and its ancillaries, including research, to increase their efforts, Pinkowski indicated that the government would raise funds to create favourable conditions for "the whole of agriculture - all productive private farms". "We should like every farmer to feel that his work is secure", he added. "We want him to know that his intentions and production plans, his desire to 